\title{
Kajian Atmosfer Saat MCC (Mesoscale Convective Complex) di Papua Barat (Studi Kasus 14 Agustus 2017)
}

\author{
Ayu Vista Wulandari ${ }^{*}$, Wishnu Agum Swastiko ${ }^{2}$, Andreas Kurniawan Silitonga ${ }^{3}$, Hariadi ${ }^{3}$ \\ ${ }^{1}$ Stasiun Meteorologi Beringin Barito Utara \\ ${ }^{2}$ Subbid Manajemen Observasi Permukaan, BMKG \\ ${ }^{3}$ Sekolah Tinggi Meteorologi Klimatologi dan Geofisika \\ ${ }^{*}$ E-mail: ayu.vista10@gmail.com
}

\begin{abstract}
ABSTRAK
Mesoscale Convective Complex (MCC) merupakan salah satu jenis dari Mesoscale Convective System (MCS). MCC membentuk sistem awan badai yang luas akibat dari banyaknya sel tunggal awan Cumulunimbus yang berkumpul dan tumbuh sehingga disebut gugusan awan konvektif berskala meso. Pada 14 Agustus 2017 terbentuk MCC di wilayah Papua Barat dengan masa hidup dari pukul 14.00 hingga 19.00 UTC. Fenomena MCC tersebut menghasilkan hujan yang berlangsung cukup lama dan bersifat terusmenerus. Penelitian ini bertujuan untuk mengkaji kondisi atmosfer saat terjadinya MCC di Papua Barat pada 14 Agustus 2017. Kajian ini menggunakan data reanalysis dari ECMWF berupa parameter komponen angin meridional dan zonal, vortisitas, dan kelembaban udara. Selain itu, juga perlu dikaji dengan menggunakan citra satelit Himawari 8 dan data Radiosonde. Dari komponen angin meridional dan zonal pada pukul 06.00-24.00 UTC terdapat angin yang cukup kencang di Papua Barat dengan arah pergerakan ke barat laut hingga utara. Berdasarkan kajian sementara, nilai vortisitas lapisan 500 mb pada pukul 06.0024.00 UTC bernilai negatif yang mengindikasikan adanya sirkulasi siklonik pada troposfer bagian tengah. Kondisi tersebut didukung dengan nilai kelembaban udara yang berkisar antara 70-100\% yang menunjukkan kondisi lapisan pada saat kejadian relatif basah. Pada citra satelit Himawari menunjukkan adanya gugusan awan Cumulonimbus dengan suhu puncak -80 OC dan berdiameter sekitar $200 \mathrm{~km}$, yang bercampur dengan awan jenis lain. Sehingga, MCC tersebut tergolong pada MCS kategori beta.
\end{abstract}

Kata kunci: MCC, awan cumulonimbus, fenomena skala meso

\begin{abstract}
Mesoscale Convective Complex (MCC) is one type of Mesoscale Convective System (MCS). MCC forms a large storm cloud system from the larger number of single Cumulonimbus cells that converge and grow into a meso-scale convective cloud cluster. On August 14th, 2017 MCC formed in West Papua with a lifetime from 14:00 to 19:00 UTC. The MCC phenomenon produced rain that lasts long enough and continuous. This study aims to assess the condition of the atmosphere during the occurrence of MCC in West Papua on August 14, 2017. This study uses reanalysis data from $E C M W F$ in the form of meridional and zonal wind component, vorticity, and air humidity parameters. In addition, it also needs to be studied by using Himawari 8 satellite imagery and Radiosonde data. From the meridional and zonal wind components at 06.00-24.00 UTC, there is a fairly strong wind in West Papua with the direction of movement from the northwest to north. Based on preliminary study, the coefficient of $500 \mathrm{mb}$ layer vortices at 06.00-24.00 UTC is shown negative which indicates cyclonic circulation in the central troposphere layer. This condition is supported by the value range of air humidity between 70-100\% which indicates the layers condition at that time is relatively wet. In Himawari 8 satellite imagery shows a cluster of Cumulonimbus clouds with a peak temperature reached -80 0C and a diameter was about $200 \mathrm{~km}$, which is mixed with other types of clouds. Thus, that MCC is classified as a beta category MCS.
\end{abstract}

Keywords: MCC, cumulonimbus, meso scale phenomena 


\section{PENDAHULUAN}

Secara geografis wilayah Indonesia berada pada garis khatulistiwa sehingga menerima panas matahari secara terusmenerus (daerah surplus energi). Indonesia juga dijuluki sebagai negara maritim karena sebagian besar merupakan wilayah lautan, sehingga aktivitas penguapan sangat tinggi. Ketersediaan uap air yang lembab menjadi bahan utama pembentukan awan-awan konvektif yang terbentuk dari proses konveksi, sehingga massa udara akan bergerak naik dan membawa panas ke lapisan atasnya dan mengakibatkan kondisi atmosfer menjadi labil. Kondisi ini mengakibatkan tumbuhnya awan-awan konvektif diantaranya yang paling berbahaya adalah Cumulonimbus.

Ketika awan-awan konvektif tersebut tumbuh, matang, meluas, dan memiliki waktu hidup yang lebih lama maka biasanya disebut sebagai Mesoscale Convective System (MCS). Salah satu jenis Mesoscale Convective System (MCS) yang terbesar yaitu Mesoscale Convective Complex (MCC). Karakteristik MCC berdasarkan Maddox $^{1}$ yaitu memiliki suhu selimut awan sebesar $\leq-32^{\circ} \mathrm{C}$ yang mewakili area stratus dengan luasan $\geq 100.000 \mathrm{~km}^{2}$, dan suhu inti awan sebesar $\leq-52^{\circ} \mathrm{C}$ sebagai area konvektif dengan luasan $\geq 50.000 \mathrm{~km}^{2}$. Menurut Ismanto $^{2}$, terdapat daerah-daerah kemunculan MCC yang sering terjadi yaitu di Samudra Hindia barat Pulau Sumatra, area Pulau Papua, Samudra Pasifik Utara Papua, Area Pulau Kalimantan, dan Samudra Hindia Utara Australia. Banyaknya terdapat MCC di wilayah Indonesia dikarenakan kondisi perairan yang hangat akibat adanya siklus radiasi musiman.

Berdasarkan data dari citra satelit, pada tanggal 14 Agustus 2017 terbentuk MCC di wilayah Papua Barat dengan masa hidup dari pukul 14.00 hingga 19.00 UTC. Fenomena MCC tersebut menghasilkan hujan yang berlangsung cukup lama dan bersifat terusmenerus. Penelitian ini akan mengaji bagaimana keadaan atmosfer saat terjadinya MCC di wilayah Papua Barat dan mengetahui tahap-tahap pembentukan MCC pada saat tanggal kejadian tersebut sehingga dapat diketahui karakteristik untuk memprediksi munculnya MCC sebagai bahan pembuatan prakiraan dan peringatan dini.

\section{METODE}

Adapun data-data yang digunakan untuk melakukan penelitian ini adalah sebagai berikut:

a. Data citra satelit Himawari-8 kanal IREnhanced tanggal 14 Agustus 2017 digunakan untuk melihat pergerakan dan kondisi awan pada saat kejadian.

b. Data reanalysis dari ECMWF berupa parameter komponen angin meridional dan zonal lapisan $500 \mathrm{hPa}$ dan $850 \mathrm{hPa}$ tanggal 14 Agustus 2017.

c. Data vortisitas tanggal 14 Agustus 2017 lapisan $500 \mathrm{hPa}$ dan $850 \mathrm{hPa}$ dari data reanalysis ECMWF untuk mengetahui pola siklonik yang mendukung pertumbuhan awan konvektif.

d. Data kelembaban 14 Agustus 2017 lapisan $500 \mathrm{hPa}$ dan $850 \mathrm{hPa}$ dari data reanalysis ECMWF untuk mengetahui keadaan kondisi atmosfer saat terjadinya MCC.

e. Data Radiosonde tanggal 14 Agustus 2017 untuk melihat kestabilan atmosfer pada saat terjadi MCC.entang metode yang digunakan dalam penelitian termasuk waktu dan tempat, bahan/cara pengumpulan data, metode analisis data.

Data-data diatas digunakan untuk mengidentifikasi karakteristik dan dampak dari MCC. Penelitian ini dilakukan dengan menggunakan data 6 jam pada tanggal 14 Agustus 2017. Adapun metode yang dilakukan dalam penelitian ini dapat diringkas sebagai berikut:

a. Data Citra Satelit Himawari 8 digunakan untuk mengetahui pola visual MCC berdasarkan suhu puncak awan yang biasanya ditunjukkan oleh suhu puncak awan yang rendah kurang dari $-40^{\circ} \mathrm{C}$.

b. Melihat pola pergerakan angin pada tanggal 14 Agustus 2017. Kemudian menginterpretasikan pola pergerakan angin tersebut untuk mengetahui keadaan yang terjadi saat adanya MCC.

c. Menginterpretasiakan nilai vortisitas untuk mengetahui pola siklonik yang mendukung pertumbuhan awan konvektif di lapisan bawah.

d. Menginterpretasikan nilai kelembaban udara di wilayah Papua Barat untuk mengetahui keadaan kondisi atmosfer saat terjadinya MCC. 
e. Menginterpretasikan data radiosonde di wilayah Papua Barat untuk mengetahui kestabilan atmosfer saat terjadinya MCC.

\section{HASIL DAN PEMBAHASAN \\ 3.1 Analisis Citra Satelit Himawari-8}

Berdasarkan data Citra Satelit Himawari-8 seperti yang ditunjukkan pada Gambar 1, terdapat MCC pada 14 Agustus 2017 pukul 14:00 UTC. Hal ini bisa terlihat pada kanal IR-Enhanced citra satelit Himawari, terdapat awan konvektif yang menutupi Papua Barat. Suhu puncak awan berkisar antara $-28^{\circ} \mathrm{C}$ hingga $-80^{\circ} \mathrm{C}$ ketika MCC mulai terjadi, sehingga dapat dikatakan bahwa awan konvektif yang terjadi pada tanggal tersebut menunjukkan adanya sistem konvektif skala meso. Pertumbuhan awan dapat dilihat pada gambar yang ditandai dengan lingkaran merah. Pembentukan awan konvektif mulai menutupi sebagian wilayah penelitian pada pukul 14:30 UTC, kemudian terus tumbuh karena proses konveksi yang kuat. Suhu puncak awan juga menurun hingga $-100^{\circ} \mathrm{C}$ hampir di sebagian wilayah penelitian. Pada pukul 19.00 UTC, bentangan awan konvektif mulai punah dan pecah. Berdasarkan analisis citra satelit Himawari-8, MCC ini hanya bertahan sekitar 6 jam.

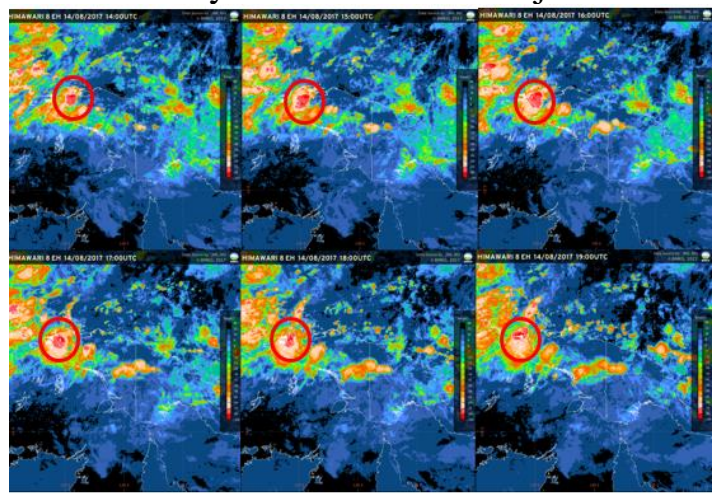

Gambar 1. Citra Satelit Himawari-8 kanal IR-Enhanced

\subsection{Analisis Komponen Angin}

Pada Gambar 2, terdapat data angin lapisan $500 \mathrm{hPa}$. Pada 14 Agustus 2017 pukul 06:00 UTC, kecepatan angin berkisar antara $15 \mathrm{~m} / \mathrm{s}$ hingga $20 \mathrm{~m} / \mathrm{s}$ yang bergerak dari timur di Papua Barat. Vektor angin yang kencang menunjukkan kecepatan angin dalam pembentukan area MCC cukup kuat. Kecepatan angin mulai meningkat seiring dengan pembentukan MCC dengan kecepatan mencapai $25 \mathrm{~m} / \mathrm{s}$.

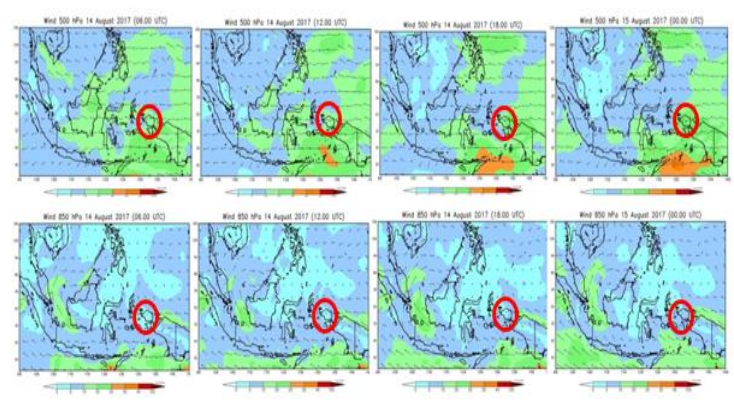

Gambar 2. Arah dan kecepatan angin lapisan $500 \mathrm{hPa}$ dan $850 \mathrm{hPa}$

Peningkatan kecepatan angin menghasilkan asosiasi massa udara pembentuk awan konvektif di Papua Barat yang dapat membentuk MCC. Peningkatan kecepatan angin masih terjadi hingga 15 Agustus 2017 pukul 00.00 UTC. Sedangkan pada lapisan $850 \mathrm{hPa}$, kecepatan angin hanya berkisar antara $2 \mathrm{~m} / \mathrm{s}-10 \mathrm{~m} / \mathrm{s}$ dan tidak ada peningkatan yang signifikan seiring dengan terjadinya MCC.

\subsection{Analisis Vortisitas}

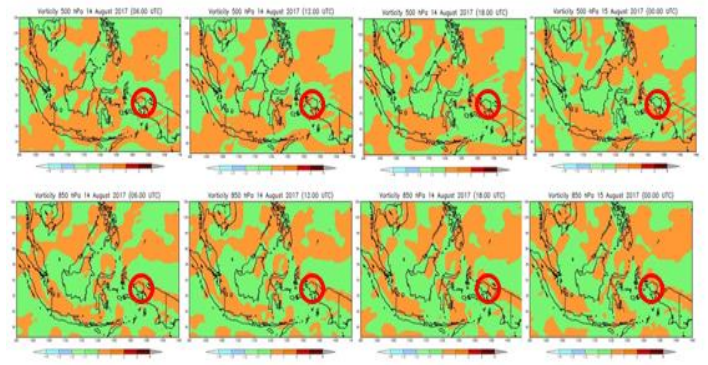

Gambar 3. Vortisitas lapisan $500 \mathrm{hPa}$ dan $850 \mathrm{hPa}$

Pada lapisan $500 \mathrm{hPa}$ dan $850 \mathrm{hPa}$, nilai vortisitas di wilayah Papua Barat menunjukkan nilai negatif berkisar dari 0 hingga -2 sebelum pukul 12.00 UTC pada 14 Agustus 2017 dan terus menguat hingga 00.00 UTC pada 15 Agustus 2017. Nilai vortisitas negatif mengindikasikan bahwa terdapat sirkulasi siklonik pada lapisan tersebut. Hal ini juga menunjukkan gerakan rotasi vertikal yang mendukung pertumbuhan awan konvektif di lapisan tersebut. 


\subsection{Analisis Kelembaban Udara (RH)}

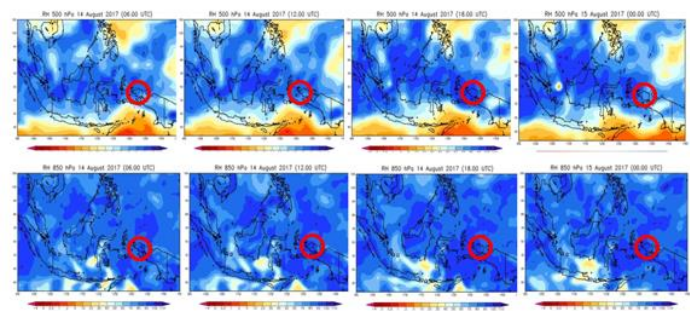

Gambar 4. Kelembaban Udara lapisan 500 $\mathrm{hPa}$ dan $850 \mathrm{hPa}$

Nilai RH dari lapisan $500 \mathrm{hPa}$ berkisar antara $70 \%$ hingga $100 \%$ yang menunjukkan bahwa terdapat kelembaban yang cukup yang tersedia sebagai bahan bakar atau pemasok utama energi dari awan konvektif untuk berkembang dan bertahan hidup. Sementara pada lapisan $850 \mathrm{hPa}$ nilai $\mathrm{RH}$ lebih tinggi dari lapisan $500 \mathrm{hPa}$ yaitu berkisar antara 90\% hingga 100\%. Kelembaban udara yang tinggi ini dapat digunakan sebagai indikasi kuat bahwa wilayah tersebut adalah daerah yang baik dan mendukung pertumbuhan awan konvektif.

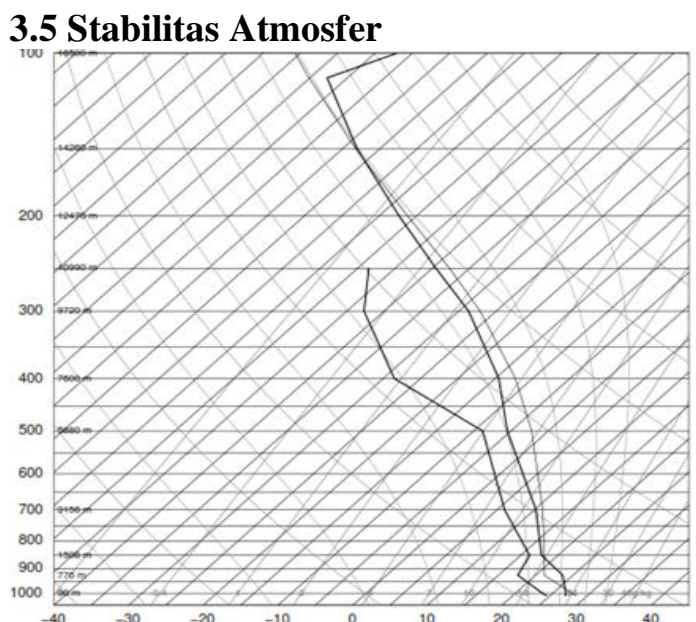

Gambar 5. Data radiosonde dari Stasiun Meteorologi Biak pukul 12.00UTC

Untuk mengetahui tentang stabilitas atmosfer suatu wilayah, dapat menggunakan data radiosonde dari Stasiun Meteorologi. Biak adalah salah satu daerah di Papua Barat yang memiliki Stasiun Meteorologi. Data radiosonde memiliki beberapa indeks stabilitas untuk memudahkan identifikasi fenomena MCC dari proses konveksi. Convective Available Potential Energy (CAPE) adalah ukuran jumlah energi yang tersedia untuk konveksi. CAPE secara langsung terkait dengan kecepatan vertikal potensial maksimum dalam suatu updraft. Dengan demikian, nilai yang lebih tinggi menunjukkan potensi lebih besar untuk cuaca buruk.

Tabel 1. Indeks Stabilitas data Radiosonde dari Stasiun Meteorologi Biak

\begin{tabular}{|l|l|}
\hline Indeks & Nilai \\
\hline CAPE & 974.5 \\
\hline K-Index & 35.30 \\
\hline Showalter Index & -1.06 \\
\hline
\end{tabular}

Berdasarkan hasil, nilai CAPE yang diamati yaitu sekitar 974,5 J/kg yang hampir mencapai $1000 \mathrm{~J} / \mathrm{kg}$. Dari nilai tersebut, dapat disimpulkan bahwa terdapat konvektif sedang pada daerah penelitian. K-Index mewakili pengukuran potensi badai petir atau awan Cumulonimbus. Nilainya mencapai 35,30 yang berarti probabilitas terjadinya badai adalah $60-80 \%$. Indeks Showalter sebesar -1,06, nilai negatif menunjukkan bahwa terdapat potensi terjadinya badai di daerah tersebut.

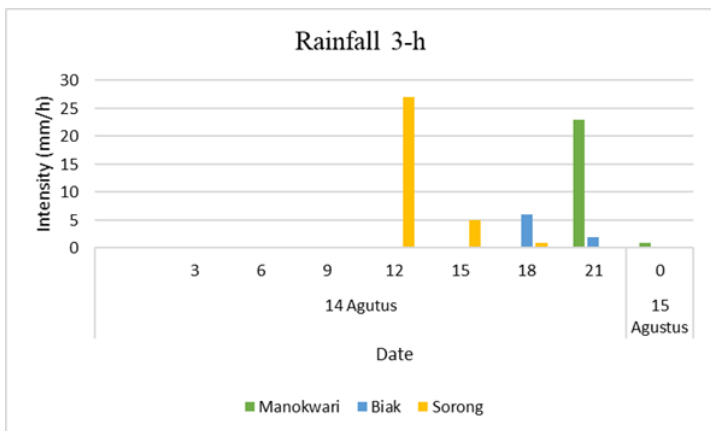

Gambar 6. Hujan 3 jaman dari Stasiun Meteorologi di Papua Barat

Gambar di atas menunjukkan bahwa selama fenomena MCC, terdapat hujan di beberapa daerah. Meskipun curah hujan tidak persis terjadi tepat di wilayah MCC yang dibentuk, curah hujan masih terus terjadi di beberapa wilayah karena penyebaran gugusan awan tersebut. Intensitas curah hujan maksimum tercatat di Stasiun Meteorologi Sorong sebesar $27 \mathrm{~mm} / \mathrm{jam}$.

\section{KESIMPULAN}

Berdasarkan hasil analisis diatas, maka didapat kesimpulan sebagai berikut:

a. Dari gambar citra satelit Himawari kanal IR-Enhanced, terdapat awan konvektif yang menutupi Papua barat dengan suhu puncak awan berkisar antara $-28^{\circ} \mathrm{C}$ hingga $-80^{\circ}$ C. MCC ini hanya berlangsung sekitar 4 jam. 
b. Kecepatan angin berkisar antara $15 \mathrm{~m} / \mathrm{s}$ - $20 \mathrm{~m} / \mathrm{s}$ dari timur di Papua Barat. Vektor angin yang kencang menunjukkan kecepatan angin dalam pembentukan area MCC cukup kuat. Peningkatan kecepatan angin menghasilkan asosiasi massa udara yang membentuk awan konvektif di Papua Barat untuk membentuk MCC. Peningkatan kecepatan angin masih terjadi hingga 15 Agustus 2017 pukul 00.00 UTC.

c. Nilai vortisitas negatif mengindikasikan bahwa terdapat sirkulasi siklonik pada lapisan tersebut. Nilai yang ditunjukkan berkisar dari 0 hingga -2 sebelum pukul 12.00 UTC pada 14 Agustus 2017.

d. Nilai RH pada lapisan $500 \mathrm{hPa}$ hingga $850 \mathrm{hPa}$ rata-rata berkisar antara $70 \%$ $100 \%$ yang menunjukkan bahwa terdapat kelembaban yang cukup yang tersedia sebagai bahan bakar atau pemasok utama energi dari awan konvektif untuk berkembang dan bertahan hidup. Nilai yang lebih tinggi ini akan menjadi indikasi kuat bahwa wilayah tersebut adalah wilayah yang baik dan mendukung pertumbuhan awan konvektif.

e. Berdasarkan stabilitas atmosfer, nilai beberapa indeks menunjukkan bahwa di wilayah tersebut memiliki probabilitas terjadinya badai petir atau awan konvektif. Hal itu dapat dilihat dari nilai CAPE, K-Index, dan Showalter Index yang memiliki nilai yang mendukung fenomena MCC yang terjadi di Papua Barat. Fenomena ini juga menyebabkan hujan lebat di beberapa daerah. Curah hujan maksimum terjadi di Sorong yaitu sebesar $27 \mathrm{~mm} /$ jam.

\section{UCAPAN TERIMA KASIH}

Terima kasih penulis ucapkan kepada Bapak Hariadi selaku dosen yang telah membimbing dan membantu dalam proses pembuatan penelitian ini. Terima kasih juga kepada Sub-Bidang Pengelolaan Citra Satelit BMKG yang telah memberikan data satelit Himawari 8 yang merupakan salah satu data dalam penelitian ini. Penelitian ini tidak menutup kemungkinan masih banyak terdapat kekurangan sehingga diharapkan dapat memberikan kritik dan saran yang membangun.

\section{DAFTAR PUSTAKA}

Maddox R A. 1980. Mesoscale Convective Complexes American Meteorological Society, vol.61, pp 1374-1387

Ismanto H. 2011. Karakteristik Kompleks Konvektif Skala Meso Di Benua Maritim Tesis, Institut Teknologi Bandung: Bandung

Bayong T H K. 2004. Meteorologi ITB Bandung.

BMKG. 2010. Keputusan No.009 Tentang Prosedur Standar Operasional Pelaksanaan Peringatan Dini, Pelaporan, dan Diseminasi Informasi Cuaca Ekstrem, BMKG: Jakarta.

Carvalho L M V and Jones C. 2001. A Satellite Method to Identify Structural Properties of Mesoscale Convective Systems Based on the Maximum Spatial Correlation Tracking Technique (MASCOTTE) University of San Paul. Brazil.

Liu C, Zipser E J, and Nesbiti S W. 2007. Global Distribution of Tropical Deep Convection: Different Perspective from TRMM infrared and Radar Data American Meteorological Society, vol. 20, pp 489-503.

Lynch A H and Cassano J J. 2006. Applied Atmospheric Dynamics John Wiley \& Sons Ltd England.

Putri A K A. 2017. Identifikasi Karakteristik Mesoscale Convective Complex (MCC) di Wilayah Kalimantan dan Sekitarnya, Thesis Meteorology STMKG

Tjasyono B H K. 2008. Meteorologi Terapan ITB Bandung.

Yunita R. 2015. Pemanfaatan Citra Radar C-Band dalam 
Mengidentifikasi

Fase

Pertumbuhan MCS (Mesoscale

Convective Sistem) Conference of

Weather Radar Operational 2015,

vol.1, pp 134-138. 